\title{
Mainstream Religious Domain in Nepal a Contradiction and Conflict of Indigenous Communities in Maintaining the Identity, Race, Gender and Class
}

\author{
https://doi.org/10.21272/sec.3(1).99-115.2019
}

\section{Medani P. Bhandari}

PhD, Professor and Deputy Program Director of Sustainability Studies, Akamai University, Hawaii, USA, Professor of Economics and Entrepreneurships, Sumy State University, Ukraine

Nepal is certainly one of the more romanticized places on earth, with its towering Himalayas, its abominable snowmen, and its musically named capital, Kathmandu, a symbol of all those faraway places the imperial imagination dreamt about. And the Sherpa people ... are perhaps one of the more romanticized people of the world, renowned for their mountaineering feats, and found congeal by Westerners tour their warm, friendly, strong, self-confident style" (Sherry Ortner, 1978: 10).

"All Nepalese, whether they realize it or not, are immensely sophisticated in their knowledge and appreciation cultural differences. It is a rare Nepalese indeed who knows how to speak only one language" (James Fisher 1987:33).

\begin{abstract}
Nepal is unique in terms of culture, religion, and geography as well as in its Indigenous Communities (IC). There has always been domination by the mainstream culture and religion; however, until recently there was no visible friction and violence between any religious groups and ICs. Within the societal structure, there was an effort to maintain harmonious relationships, at least on the surface. In recent years discord has emerged primarily due to political crises as well as an identity crisis among ICs. In practice, until recently, the majority of the people, including the ICs but with the exception of the hardliner Muslims and Christians, respected or worshiped the same deities one way or another. Social harmony also has been reinforced by the interdependence of the peoples living in Nepal's different geographical terrains, whose survival has depended on intergroup cooperation. These relationships, however, are breaking down slowly as part of a process of social transformation centered on the evolving identity of ICs, which is having a positive impact on their wellbeing. This paper examines the stake of ICs, which has been a major issue of discussion in the wave of ongoing constitution preparation processes.

This paper summarizes the arguments and counterarguments within the scientific discussion on the issue culture, religion, and geography as well as in its Indigenous Communities (IC). The main purpose of the research is to explore the harmonious relationships among various languages and religious as well as indigenous communities. Systematization literary sources indicates that socio-cultural harmonies and inter-relationships among the different religious, ethnic and indigenous communities is building and social transformation is occurring. The relevance of the decision of this scientific problem was social stratification, however social strata are narrowing slowly. Methodological tools of the research methods were empirical completely based on secondary sources and personal observation of about five years of research on the process of social transformation. The object of research is based on Nepal, where about 125 languages are spoken and dominantly Hindu, however Buddhist, Islam, Christianity and other religions have been practiced harmoniously. The paper presents the results of an empirical analysis based on secondary sources and, which showed that paper demonstrates the positive impact of government policy directives on the acceptance of indigenous knowledge and the social wellbeing of ICs. The research empirically confirms and theoretically proves that social and cultural transformation has been occurring in Nepal, however the change pattern is relatively slow. The results of the research can be useful for the socio-cultural researchers as well as for the policy makers and general readers who are willing to know the harmony of social inclusion.
\end{abstract}

Keywords: indigenous communities (Adhivasi), ethnic group (Janajati), caste system, religion, identity, social transformation. 
JEL Classification: Z00, Z12.

Cite as: Bhandari, M. P. (2019). Mainstream Religious Domain in Nepal a Contradiction and Conflict of Indigenous Communities in Maintaining the Identity, Race, Gender and Class. SocioEconomic Challenges, 3(1), 99-115. https://doi.org/10.21272/sec.3(1).99-115.2019.

(C) The Author, 2019. This article is published with open access at Sumy State University.

\section{Introduction}

The historic situation of Nepal, if not unique, is certainly unusual. Nepal clearly shares in the long and great history of Asian civilization, intricately involved with the Buddhist and Hindu religions. Buddha himself was born within the boundaries of present-day Nepal and much of Hindu mythology involves the Himalayan region. That Nepal formed an integral part of ancient Asian civilization is further attested to by many facts, of which the origins of pagoda architecture in Nepal and the early reference in Hiuen Tsang to Nepal in Chinese writings are but two. The unusual feature of Nepal lies in the fact that here an integral part of Asian civilization remained almost uninfluenced by colonialism, the industrial revolution, and European technology until the mid-twentieth century (Griffin et al., 1988: 44).

Nepal has been a kingdom for at least 1,500 years. During most of that period, the Kathmandu Valley has been Nepal's political, economic, and cultural center. The valley's fertile soil supported thriving village farming communities, and its location along trans-Himalayan trade routes allowed merchants and rulers alike to profit. Since the fourth century, the people of the Kathmandu Valley have developed a unique variant of South Asian civilization based on Buddhism and Hinduism but influenced as well by the cultures of local Newar citizens and neighboring Tibetans. One of the major themes in the history of Nepal has been the transmission of influences from both the north and the south into an original culture. During its entire history, Nepal has been able to continue this process while remaining independent (Savada, 1991). In this regard various sources (including publication in Nepali, Hindi languages and Sanskrit) have dated Nepali history from the birth year of the Buddha in 563 B.C. in Lumbini, Nepal (Kirk Patric, 1811; Hodson, 1817; Hamilton, 1819; Oldfield, 1880; Petech, 1958; Regmi, 1960; Karan, 1960; Khanal, 1966; Thapa, 1967; Husain, 1970; Giuseppe da Rovato, 1970; Whelpton, 2005).

Nepal was never colonized, in spite of several attempts by the British in India; however, after the Sunauli treaty of 1816 (which was the outcome of a six-year war with the British and reduced the size of Nepal by $\left.1 / 3^{\text {rd }}\right)$, Nepal was isolated from the rest of the world for about 130 years, except for contact with Britain and the British ruler in India. However, isolated Nepal faced dreadful events internally due to the power greediness of the rulers, who were ritually high ranking in the Hindu case system, and who always suppressed ethnic communities and groups (Whelpton 2005).

Over a period of 122 out of 134 years, the Nepalese people had to go through a variety of autocratic rulers. It is a historical reality that there has been a rapidly expanding process of globalization and the intensification of a previous policy. There has been cultural violence through the domination of one caste, one religion, one language and one culture, the very process of marginalization or peripheralization, and grinding poverty. Nepal has also suffered from isolation, due to a lack of transportation. Communication and education have indeed helped, on the one hand, to keep some of the traditional local governance intact, and on the other hand, many of them were either lost or at the verge of extinction (Bhattachan, 2008).

Although rulers changed, the disregarding ethnic minority continues even under the current political regime.

\section{Current Nepal}

Nepal shares a 1590-kilometer-long border with India and 1414 kilometers with China (Dahal, 2004; Bhattarai, 2005) and the elevation of the country increases from about 60 meters in the south to 8848 meters in the north at the peak of Mt. Everest. It has four major ecological zones: a) Lowland, also known as "Terai,"60 to 900 meters from sea level, b) Midland 900 to 2500 meter from the sea level, c) Highland 2500 to 2750 meter from the sea level, and d) Trans-Himalayan 2750 to 8848 meter from sea level (NPC, 2008). Religiously and culturally these zones also maintain different identities: whereas the Terai's lowland shares common traditions with India (in the south), in the northern part, the Trans-Himalaya border with Tibet has limited influence from Chinese culture due to the geographical terrain; but Tibetan dialects are still spoken in and north of the higher Himalayas where standard literary Tibetan is widely understood by those with religious education; 
Maithili and Hindi or other common languages of India and Nepal are spoken in the southern part of the country (CBS, 2004, 2011, 2018). The figure below shows an ethnographic overview of the country, which is bounded by India from the West, South, and East and China on the North.

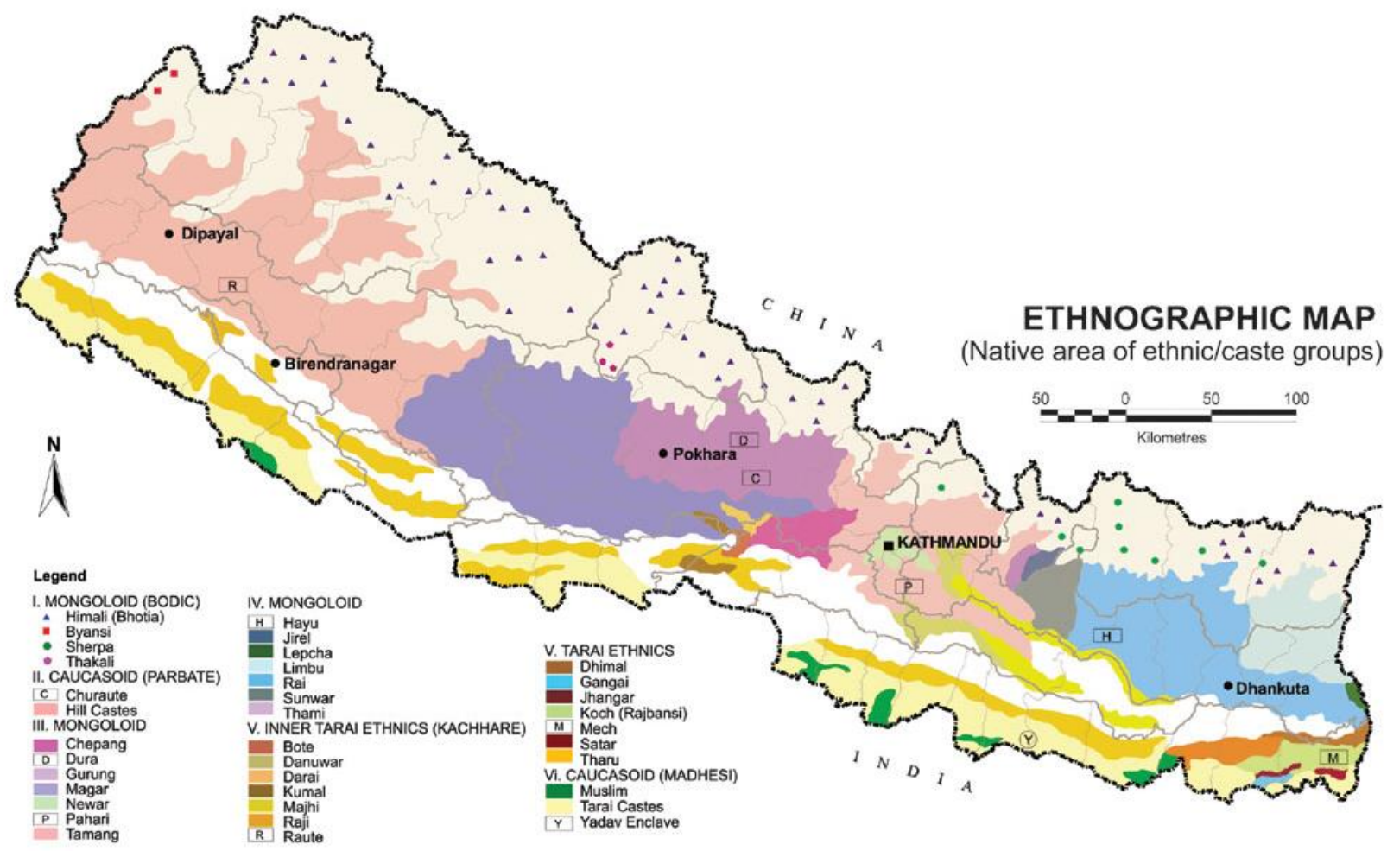

Figure 1. Ethnographic division of Nepal

Source: Gurung (1996) as in Turin (2007).

Figure 1 shows the ethnographic diversity and the situation of Indigenous Nationalities of Nepal; it is worthy of note that Eastern Nepal holds a more diverse population in relation to the West.

Nepal has an open border system with India and has been influenced across the social, cultural and political systems. Most Nepali social movements, including the civil society, democratic, indigenous peoples' rights, human rights, women's rights, environmental conservation movement, have been influenced by India directly or indirectly.

\section{Religious and cultural complexity in Nepal}

Nepal has a socially, religiously, culturally and politically diverse society. It has long religious bonds to the Hindu caste system, Buddhist architecture based on PanchaSila (five duties and responsibilities), the Muslim religion system and several ethnic communities and groups. Each of them practices their own socio-cultural traditions. Hindu society in Nepal constitutes a large majority and still follows the tradition of ritually ranked hierarchical status based on the caste system; where the "pure caste" status is still high particularly in the rural and hill communities. As noted in Berreman (1972: 198) caste consists of ranked endogamous divisions of society in which membership is permanent and hereditary. Similarly, Dongol (2005: 23) notes that the caste system directs Hindu society into four different hierarchical categories; Brahman, Chhetri, Vaishya and Shudra. This social hierarchy ranks the Nepalese along an axiom of purity and pollution. Under this, Brahman, Chhetri and Vaishya are considered to be ritually pure whereas Shudra are considering to be ritually polluting.

In addition to this majority-dominated Hindu society, Nepal is a multi-racial or multi-caste/ethnic, multi lingual, multi-religious and multi-cultural and more recently multi-political party country (Bhattachan, 2008). There are 44 distinct castes and 59 indigenous/ethnic communities (18 are from the mountainous region, 24 from the hills, 7 from the inner Terai and 10 from Terai). The 2001 census identified 92 languages spoken as mother tongues out of 125 commonly spoken languages, by different nationalities within a total area of 
approximately 147,181 square kilometers $(\mathrm{km})$. Linguistically, Nepal has four major language groups: IndoAryan, Tibeto-Burman, Mongolian and various indigenous language isolates; whereas Nepali is the national language and the mother tongue of 48.61 (CBS 2004), 44.64 (CBS 2011) percent of the population, it is followed by Maithili, Bhojpuri, Tharu, Tamang, Newari/Nepal Bhasa, Magar, Awadhi, Rai, Limbu, Bajjika etc. as listed in the table 1 (CBS, 2004, 2011, 2018).

Table 1. Major spoken languages of Nepal

\begin{tabular}{|l|c|c|c|}
\hline \multicolumn{1}{|c|}{ Languages } & CBS, 2004 & CBS, 2011 & Increase/Decrease \\
\hline Total Population No & 23151423 & 26494504 & +3343081 \\
\hline Nepali & $\%$ & $\%$ & Change in\% \\
\hline Maithili & 48.61 & 44.64 & -3.97 \\
\hline Bhojpuri & 12.30 & 11.67 & -0.63 \\
\hline Tharu & 7.53 & 5.98 & -0.09 \\
\hline Tamang & 5.86 & 5.77 & -0.08 \\
\hline Newari & 5.19 & 5.11 & -0.43 \\
\hline Magar & 3.63 & 3.20 & -0.41 \\
\hline Avadhi & 3.39 & 2.98 & -0.58 \\
\hline Bantawa & 2.47 & 1.89 & -2.19 \\
\hline Rai & & 0.50 & -0.17 \\
\hline Gurung & 2.79 & 0.60 & -1.94 \\
\hline Limbu & & 1.23 & 1.30 \\
\hline Bajjika & 1.47 & 2.99 & 2.61 \\
\hline Urdu & 1.05 & & \\
\hline
\end{tabular}

Source: CBS, 2004, 2011.

The table shows population change

\section{Hindu Caste System also believes in Fatalism}

Integrated into the caste system in Nepali society is a belief in fatalism - a feature of Hinduism (as in India, also), but also present in Buddhism. Theoretically, in Durkheim's terms, fatalism is embedded within the social norms or, according to Dohrenwend (1959), a rule which, over a period of time, proves binding on the overt behavior of each individual in an aggregate of two or more individuals. It is marked by the following characteristics: (1) Being a rule, it has content known to at least one member of the social aggregate. (2) Being a binding rule, it regulates the behavior of any given individual in the social aggregate by virtue of (a) his having internalized the rule; (b) external sanctions in support of the rule applied to him by one or more other individuals in the social aggregate; (c) external sanctions in support of the rule applied to him by an authority outside the social aggregate; or any combination of these circumstances (Dohrenwend,1959: 470). Durkheim terms the norm-states as "pure" types in the sense that, in most empirical situations, elements of these pure types are combined to form composite varieties. The pervasiveness and relative importance of the elements of any one of the types in a given social aggregate is thus a matter of degree (Dohrenwend, 1959: 470).

Here linking with the Hindu domain, fatalism can be seen in the excessive regulations of the Manu Dharmashastra, or the Bhagavad Gita, or tracing their roots to the classical concepts of karma, dharma, the separation of actions from their results, and even the cycle of reincarnation. As Gyawali (2009) notes, the notion of Fatalists (risk-indifferent conscripted shudra donkeys) reinforces their pattern of social relations through their beliefs that they can do little to help themselves, that life is unpredictable and nature is capricious - like a ball on a flat table which can go any which way - and that the best they can do is to cope with day-to-day instructions and events (2009:21). As briefly touched on above, the primary Hindu values are centered on the concept of four basic duties (Hiriyanna, 1953): ARTHA: instrumental value related to economics, the acquisition of wealth and earthly prosperity; KAMA: psychological value of personal gratification which is an intrinsic value of human desires, without the moderate fulfilling of which no spiritual enlightenment will follow; DHARMA: moral value related to preserving social norms as well as personal fitness to lead to the next value 
of higher spiritual attainment; and MOKSHYA: or final transcendental enlightenment and liberation from the world of sorrow and rebirth therein (as in Gyawali, 2009: 18).

Hindu fatalism is also embodied in the teaching of the Gita, where, in chapter two, Theory and Practice of Karma-Yoga, it states that "You have control over doing your respective duty only, but no control or claim over the results. The fruits of work should not be your motive, and you should never be inactive" (Gita verse 2.47). There is a strong influence of Gita teaching in the Hindu domain and it is considered as a doctrine of universal truth. As the Gita states, if one does not have control over his or her work, then automatically, in the religious doctrine, the follower either believes in God's mercy or in fate. Moreover, until recently, owing to fatalism, Hindus even felt that leaders were in power because of fate, rich and poor existed due to fate, and birth in the high caste and low caste was also due to fate (Gyawali, 2009) which is based on the purity-based doctrine and can be found in other religions, as well.

In the entire Nepali society, there is still a thin understanding that "service to mankind is service to the God". However, this notion has been challenged internally and externally because of power politics and power struggle in the capital and urban areas; it was not significant in rural Nepal because of its simplicity and its relative isolation from struggles over political ideology. In urban areas, society has been transforming into a Western type of social system. There was also another tendency of transformation within society which is known as Sanskritization (Prof M.N. Srinivas introduced the term Sanskritization to Indian Sociology). The term refers to a process whereby people of lower castes collectively try to adopt upper caste practices and beliefs to acquire higher status. Western hegemony has strong influence among the elite in urban Nepal and is spreading to rural Nepal at an accelerating rate. Nonetheless, discriminatory practice embedded in Hinduism is still a major hurdle for the harmonization of Nepalese society.

\section{Discriminatory practice in Hinduism}

Discrimination in Hinduism is rooted in the caste system, evident in Nepal in the existence of the Non-Dalit and Dalit (untouchable- impure castes) in both hill and the Terai (plain) regions, as well as in rural and urban settings (UNESCO, 2006: 8). Discriminatory practice, embedded through hierarchy in the Hindu caste system of Nepal, was practiced socially and was also legally institutionalized. As Sharma notes, this system was codified in the national legal code of 1853 . The code further insists that the Nepalese discriminate among themselves on the basis of caste. This code provided more privileges to the higher caste in social, economic and legal aspects. This legal provision remained for more than a hundred years up to 1963. Although the constitution of 1963 abolished all types of discrimination on the basis of caste, there is still a caste system functioning actively in Nepalese society. In turn, the socio-economic status of untouchables remains more vulnerable (Sharma, 1977: 277-299 also in Dangol, 2005: 23-24).

However, in recent years, such tradition is breaking down due to external and internal criticism. As a consequence, there has been growing awareness of the need to protect endangered ethnic groups, and some critical steps have been taken; however, so far there is no significant change in their social pattern in serving. The ongoing steps to mainstreaming these groups are explained in the following section on transformation.

\section{The characteristics if the indigenous peoples of Nepal}

In Nepal indigenous people are termed Adivasi and Janajati, where Adivasi means the earliest or first settlers and Janajati means population groups that are outside the Hindu varna, or caste, system (United Nations, General Assembly, 2009: 6). According to the United Nations definition:

Indigenous communities, peoples and nations are those which have a historical continuity with pre-invasion and pre-colonial societies that developed on their territories; consider themselves distinct from other sectors of the societies now prevailing on those territories, or parts of them. They form at present non-dominant sectors of society and are determined to preserve, develop and transmit to future generations their ancestral territories, and their ethnic identity, as the basis of their continued existence as peoples, in accordance with their own cultural patterns, social institutions and legal system. This historical continuity may consist of the continuation, for an extended period reaching into the present of one or more of the following factors:

1. Occupation of ancestral lands, or at least of part of them. 
2. Common ancestry with the original occupants of these lands.

3. Culture in general, or in specific manifestations (such as religion, living under a tribal system, membership of an indigenous community, dress, means of livelihood, lifestyle, etc.).

4. Language (whether used as the only language, as mother-tongue, as the habitual means of communication at home or in the family, or as the main, preferred, habitual, general or normal language).

5. Residence in certain parts of the country, or in certain regions of the world.

6. Other relevant factors.

On an individual basis, an indigenous person is one who belongs to these indigenous populations through self-identification as indigenous (group consciousness) and is recognized and accepted by these populations as one of its members (acceptance by the group). This preserves for these communities the sovereign right and power to decide who belongs to them, without external interference (UN, 2009: 4-5)

This definition and the characterization of the United Nations (UN) capture the notion of Nepalese Adivasi and Janajati except the term "historical continuity with pre-invasion and pre-colonial societies that developed on their territories", because Nepal was never colonized and externally the rights of the indigenous communities were unchallenged. The UN has acknowledged this weakness of its broader definition and through its Report on the Situation of Indigenous Peoples in Nepal, where it notes that:

the Adivasi Janajati groups are aptly considered indigenous peoples within the scope of his mandate, given not just their self-identification as such, but also the history of subjugation they have suffered within a pattern of encroachment by others and the set of human rights problems they commonly face that are related to their distinct group identities. These problems, with their historical origins, are similar to those of peoples throughout the world that are identified as indigenous and that are the subjects of special international concern. Adivasi Janajati are indigenous peoples in a sui generis sense, with a status apart from that of the rest of Nepali society. This does not mean that they enjoy human rights that are in a fundamental sense unique to them and not enjoyed by other Nepalese, but rather that they share a common set of human rights issues that deserve special attention and that are addressed under the international rubric of indigenous peoples.

Additionally the UN (2009) has adopted the definition of Adivasi Janajati of Nepal from the National Foundation for Development of Indigenous Nationalities Act of 2002; which states that Adivasi Janajati, that is, indigenous peoples or nationalities, are defined as those ethnic groups or communities that "have their own mother tongue and traditional customs, distinct cultural identity, distinct social structure and written or oral history of their own" (UN, 2009: 2; also in Roy and Henriksen, 2010: 4).

This does not mean that they were not marginalized by the dominant castes who have been ruling the country from its existence. However, the traditional voluntary local governance has neither attracted the attention of social scientists, including anthropologists, nor of development practitioners (Bhattchan, 2008). Similarly, there has never been any interference in enjoying indigenous rituals of any ethnicity. What have been lacking were the efforts to bring them into the mainstream of development by helping to foster their traditional knowledge. Because of the degradation of natural resources on which most of the indigenous communities rely, some such identities have already disappeared and some of them are in the endangered stage.

The Nepalese governance system is mostly dominated by high caste people who in practice do not recognize or accept that Adivasi Janajati differ from the other, mainly Hindu- and Nepali-speaking parts of society in various ways, including in their social structures, languages, distinct cultural and religious traditions, and ways of life.

Caste based discrimination, including untouchability, originated in the Indian sub-continent more than two thousand five hundred years ago. Hindu religious scriptures, specially the Manusmriti, divided human beings in four varnas, namely, Brahman, Kshatriya, Vaisya and Sudra and their ascribed traditional roles was respectively intellectual, warrior, economic and manual work. Each varna was further divided in numerous castes and sub-castes. Varnas, caste and sub-castes are based on ascription, hierarchy, purity and pollution of water, food and body. Brahmans are at the top and Sudra at the bottom of the hierarchy. Castes and sub-castes within each varna are further hierarchically sub-divided (UNDP, 2008: 19). 
Throughout Nepal's history, the government has done little to uplift the marginalized society. Nepali society is patriarchal. Examples can be seen in the civil service system, which is not representative of Nepal's multilingual, multi-religious, and multi-ethnic society. As noted above, the Hindu caste system remains strong. As Dangol (2005:84) notes major social values in Nepal are dominated by caste. Hierarchical social structure, vertical dependency, and status-oriented attitudes are some of the factors which are a product of the caste system. The civil service system is largely dominated by the higher caste Brahmin and Chhetri, whereas these two castes occupy only 12.74 and 15.80 percent of total population (CBS, 2008: 4). However, according to the public service commission data source (2005) about 60 percent of civil service is occupied by the Brahmin followed by about 20 percent Chhetri; 5 percent Newar and the rest by other castes respectively (Dangol 2006), shown in figure 2 and 3 (based on the recruitment data). Similarly, the top-most positions also are dominated by the Brahmin, Chhetri and Newar castes in Nepal.



Figure 2. Who applies for government jobs and who gets them (by castes)

Source: Department of Civil Personnel Record (2004) ** Others include Giri, Thakali, Rai, Gurung, and other Madhesi Ethnic Group as cited in Dangol (2005: 93). 


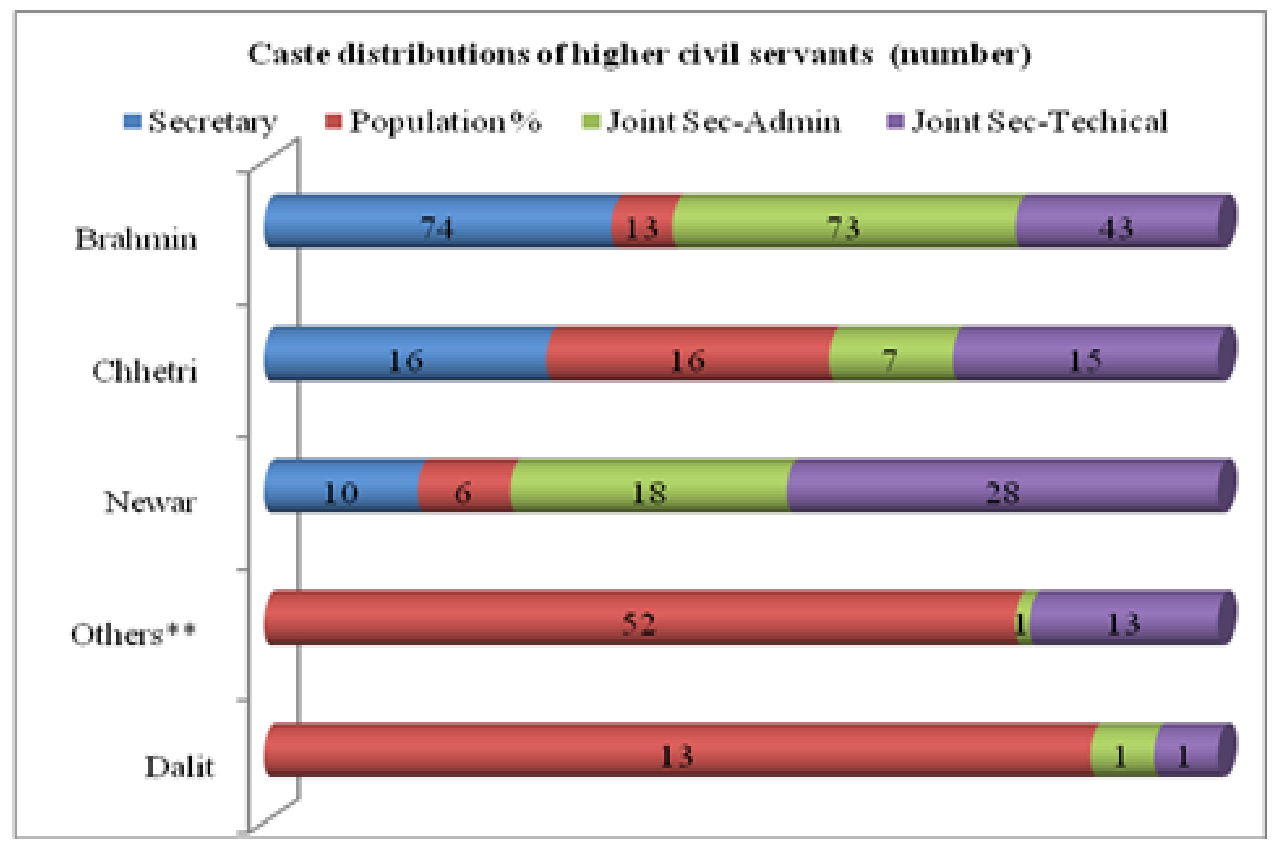

Figure 3. Seniority in civil service by castes

Source: Department of Civil Personnel Record (2004) ** Others include Giri, Thakali, Rai, Gurung, and other Madhesi Ethnic Group as cited in Dangol (2005: 95).

These two situations show the overall civil service distribution pattern of Nepal, which is dominated by male and high-caste Hindus. There are several reasons for this. By tradition Brahmins are supposed to provide education to the general public. To get into the civil service one needs to be well educated and competent for the exams. In these competitions Brahmins rank highly; however, they also get priority because the public service commission itself is also highly dominated by the Brahmin and Chhetri. Nepal does not have quota system in public service as do India and Bangladesh. However, in the parliament there is a quota for women. In the Constituent Assembly elections in 2008, more than 33 percent of women were elected through quotasystem, (UNDP, 2008).

\section{The contemporary scenarios of change}

Globally there have been several notable efforts in mainstreaming indigenous identity (Bhandari 2018). In particular, the United Nations has been addressing related human rights issues from its inception in October 24, 1945. The foundation of the U.N.'s efforts dates to December 10, 1948, when the General Assembly adopted and proclaimed the Universal Declaration of Human Rights and asked all its member countries to publicize the text "to cause it to be disseminated, displayed, read and expounded principally in schools and other educational institutions, without distinction based on the political status of countries or territories" (United Nations 1948). The right of peoples to self-determination was declared in the two International Covenants of 1966, which formulated it as a pure collective human right, in article 1 "All peoples have the rights of self-determination. By virtue of that right they freely determine their political status and freely pursue their economic, social and cultural development." According to the International Work Group for Indigenous Affairs (IWGIA) (2011), the right of self-determination has also been recognized in other international and regional human rights instruments such as Part VII of the Helsinki Final Act 1975 and Article 20 of the African Charter of Human and Peoples' Rights as well as the Declaration on the Granting of Independence to Colonial Territories and Peoples. It has been endorsed by the International Court of Justice. Self-determination is the right to participate in the democratic process of governance and to influence one's future politically, socially and culturally (IWGIA 2011). In short, this was an effort to mainstream rights. Several decades later, the UN refined these basic ideas with its Declaration on the Rights of Persons Belonging to National or Ethnic, Religious and Linguistic Minorities (A/RES/47/135), adopted by the $92^{\text {nd }}$ plenary meeting, in December 18, 1992 and the UN declaration on the Rights of Indigenous Peoples, adopted by the General Assembly on September 13, 2007 by 143 Yes, 4 No, abstentions 11, Non-Voting 34 (among the total 192 voting membership). 
The International Labor Organization (ILO), which was founded in in 1919 "as part of the Treaty of Versailles that ended World War I, to reflect the belief that universal and lasting peace can be accomplished only if it is based on social justice" (ILO 2011), has also been playing a critical role in creating a global response to address discrimination against indigenous nationalities.

ILO is the tripartite UN agency that brings together governments, employers and workers in common action to promote decent work. Nepal joined the ILO in 1966. After the provision of technical assistance through its Liaison Office and the Office of the Senior ILO Adviser during the early time, the CO-Kathmandu office was established in 2000 (ILO, 2011).

ILO has been helping Nepal to improve its capacity to produce and use labor market information, including wage trends, as a basis for informed policy decisions, and to collect and analyze consistent data to help countries benchmark their progress; to collect and disseminate information on countries' crisis response and recovery packages; to assess the actions taken and those required for the future, working with other relevant organizations; for strengthening the partnerships with regional development banks and other international financial institutions; for strengthening country-level diagnostic and policy advisory capacity; and prioritizing crisis response in Decent Work Country Program respectively (ILO-Nepal, 2010: 39). Furthermore, the ILO has been conducting research and publishing its findings to illustrate that the current governance system in Nepal is not appropriately addressing the indigenous peoples' stake and how they are marginalized. Here are a few highlights from its report of 2009, on Nepal's case.

- Indigenous peoples also face huge disparities in terms of access to and quality of education and health.... In Nepal, while some indigenous peoples... have literacy rates that surpass the national average, 30 of the country's indigenous peoples still fall far below it. ... Indigenous peoples also suffer from discrimination in terms of employment and income (2009: 22).

- Indigenous peoples' poverty has not diminished over time ... Indigenous peoples also suffer from many other disadvantages (28).

- International human rights instruments such as the Universal Declaration of Human Rights, the International Covenant on Economic, Social and Cultural Rights, the Convention on the Elimination of All Forms of Discrimination against Women and the Convention on the Rights of the Child have traditionally provided the legal framework for the foundation of international human rights, including the right to health (158). However, there is a Gap in life expectancy between indigenous and non-indigenous people; for example, in Guatemala 13; Panama 10; Mexico 6; Nepal 20; Australia 20; Canada 7; and New Zealand 11 respectively (ILO, 2009: 159).

However, the ILO also accepts the notion that change has been occurring in different parts of the world and that differential progress is being made by indigenous peoples in their social and economic development, reflecting specific national legal and policy frameworks with regard to recognizing, respecting and promoting their rights (22). This notion also incorporates the Nepalese indigenous nationalities basically due to the change in the religious population, as shown in table 1: Religious population change in Nepal 1952-54, 1991, 2001 and 2011.

Table 2. Religious population change in Nepal 1952-54, 1991, 2001 and 2011

\begin{tabular}{|l|c|c|c|c|c|c|c|c|}
\hline \multicolumn{1}{|c|}{ Religion } & $1952-1954$ & $\%$ & 1991 & $\%$ & 2001 & $\%$ & 2011 & $\%$ \\
\hline Hindu & $7,138,392$ & 88.8 & $15,996,953$ & 86.5 & $18,330,121$ & 80.6 & 21551492 & 81.34 \\
\hline Buddhists & 707,104 & 8.6 & $1,439,142$ & 7.8 & $2,442,520$ & 10.7 & 2396099 & 9.05 \\
\hline Islam & 208,899 & 2.6 & 653,218 & 3.5 & 954.023 & 4.2 & 1162370 & 4.39 \\
\hline Kirat & & & 318.389 & 1 & 818,106 & 3.6 & 807,169 & 3.05 \\
\hline Christian & & & 31,280 & 0.2 & 101.976 & 0.5 & 375,699 & 1.42 \\
\hline Jain & & & 7,561 & 0 & 4.108 & 0 & 3214 & 0.01 \\
\hline Sikh & & & 9,292 & 0.1 & 5,890 & 0 & 609 & 0.002 \\
\hline Other & 6,840 & 0 & 17,124 & 0.1 & 86,080 & 0.4 & 136,271 & 0.04 \\
\hline Unidentified & & & 18,138 & 0.1 & & & 61581 & 0.23 \\
\hline Total & $8,061,235$ & & $18,173,026$ & & $21,683,777$ & & $26,494,504$ & \\
\hline
\end{tabular}

Source: Bhattachan (2008), CBS (2004, 2011, 2018). 
This table gives a snap shot of only the years from 1952 to 2011, but it is sufficient to summarize long-term trends. For example, the table shows that in 1952-54, the population was 88.8 percent Hindu, but there was no count or acknowledgement of existence of the Kirat, Christians, Jains and Sikhs. In the population census of 1991 (I served as a census supervisor in 1991 and 2001), those religious groups were identified. A similar count was repeated in the 2001 and 2011 census; however, there were no unidentified groupings. As a general notion, when population growth occurs obviously the number in the category increases, which is depicted in the table. However, it is noteworthy to see the change in percentage. The trend shows that the Hindu population is decreasing relative to the whole, while the Jain and Sikh and the Kirat percentages are increasing. As the census supervisor I interviewed people in some of the villages, where in 1991, they identified themselves as Hindu and in 2001 as Kirati. When I tried to get clarification of this contrast, the local elders noted that, they are in the process of reclaiming their indigenous identity, which was not possible during the 1990s. This notion indicates an emerging challenge to Hindu domination, which largely used to conflict with other religious groups, including Buddhist, Animist, Bon, Kirata, Islam and Christian (CBS, 2011, 2018).

In Nepal, basically, the traditional basis of the Hindu dominated system began to be challenged after the success of the first political movement of Nepal in 1990, which re-introduced the country to the democratic era. In 1995 a Maoist insurgency challenged religious doctrines. They utilized the marginalized Adivasi Janajati young by recruiting them into their militia. During the Maoist insurgency more than 15,000 people lost their lives; among them the major victims were the Adivasi Janajati, toward whom both the government authorities and the Maoists had suspicious attitudes. However, in November 2005, the Maoist rebels and the main opposition parties agreed on a program intended to restore democracy. And in April 2006 the People's Movement II called for the re-installation of the Parliament. In November 2006, ultimately the Maoist insurgency ended with the signing of the Comprehensive Peace Agreement between the government and the Maoists. This process brought a significant change in the Adivasi Janajati stake in the Nepalese civil service system. As a consequence, in August 2007 the Civil Service Act was amended to include a provision for $45 \%$ of the vacant seats to be reserved for women, Dalits, Adivasi Janajatis, Madhesis and those from 'backward' regions. The year 2007 became the most fruitful year in Nepalese history for indigenous groups when the ILO Convention on Indigenous and Tribal Peoples of 1989 (No. 169) was ratified by the Interim Parliament which also adopted the UN Declaration on the Rights of Indigenous Peoples in the UN General Assembly.

"ILO Convention No. 169 also enshrines the importance of self-identification. Article 1 indicates that self-identification as indigenous or tribal shall be regarded as a fundamental criterion for determining the groups to which the provisions of this Convention apply: a) tribal peoples in independent countries whose social, cultural and economic conditions distinguish them from other sections of the national community and whose status is regulated wholly or partially by their own customs or traditions or by special laws or regulations; b) peoples in independent countries who are regarded as indigenous on account of their descent from the populations which inhabited the country, or a geographical region to which the country belongs, at the time of conquest or colonization or the establishment of present state boundaries and who irrespective of their legal status, retain some or all of their own social, economic, cultural and political institutions" (UN, 2009: 5-6).

In addition Nepal has ratified most of the major international human rights conventions, such as the International Convention on the Elimination of All Forms of Racial Discrimination, the International Covenant on Civil and Political, the International Covenant on Economic, Social and Cultural Rights, the Convention on the Elimination of All Forms of Discrimination against Women, the Convention on the Rights of the Child, and the Convention against Torture and Other Cruel, Inhuman or Degrading Treatment or Punishment (Roy and Henriksen, 2010: 4).

With socio-political motives the Government of Nepal ratified the ILO Convention 169. However, it is not easy to implement because of the dominance of Hindu high caste officials who still control the countries' socio-economic and political and civil service sectors. High caste people hold a feudal mentality and are not only reluctant to implement the conventions but also resist change. The present, major challenge is: how to remove the legacy of the feudal mind-set of the dominant caste groups. Similarly, as Gurung (2009: 1-5) notes:

- It is also a challenge to define the rights to self-determination and ethnic autonomy, because the indigenous peoples of Nepal do not have deep trust in the government for sharing power and implementing international human rights conventions; they demand their own rule through the transformation of state structure. 
- ILO Convention 169 is concerned more with the rights of indigenous peoples over their traditional lands, forests, water and other natural resources. Because indigenous peoples claim their rights over the land and natural resources, these have become a contested issue in Nepal as many other non-indigenous settlers also have settled in the same geo-ecological regions and have used the natural resources for their livelihood.

- Lack of Adequate Resources and Effective Mechanisms: the UN and other international agencies which promote these conventions do not have special funds nor do they have any effective mechanism to supervise and monitor the implementation of these conventions.

As outlined above, there are a few problems in implementation the convention. Whatever the motives were behind the ratification of the convention, it is now active and has gained very good recognition for Nepal. The ILO Country Director for Nepal, Shengjie Li's response nicely articulates Nepal's position:

ILO Convention 169 concerns indigenous people, and 37 per cent of Nepal's population is made up of 59 different groups of indigenous peoples. Not many countries in the world have such indigenous diversity in their population. If you look at the decade-long conflict it is clear that the social exclusion of the indigenous people contributed to the war. This is why ILO promoted the ratification of this Convention for almost a decade and Nepal ratified the Convention in 2007. It is significant that Nepal is the first country to ratify the Convention in the South Asian region, and the second country in the Asia-Pacific region. There are a lot of indigenous people in Myanmar, Bangladesh, Indonesia and Philippines, but those countries haven't ratified the Convention yet. We hope that Nepal can use this Convention as a dialogue tool for the peacebuilding process (Dr. Shengjie Li interview to the Nepali Times, 2011)

The media and civil society organizations of Nepal have been supportive role in mainstreaming human rights, women's rights and indigenous rights and also have been playing a safeguarding role to implement publicconcerned conventions, covenants and treaties. There is also a growing trend for indigenous peoples' civil societies. For example, the Nepal Federation of Indigenous Nationalities (NEFIN) is an umbrella organization of indigenous peoples' organizations representing the 59 indigenous nationalities (Bhattachan and Webster 2005). It is too early to draw conclusions that ILO Convention 169 will be completely implemented but some good initiatives are already in practice.

For example, the government's Three-Year Interim Plan included specific promises for Adivasi Janajati inclusion. In 2008, the government of Nepal and the Adivasi Janajati party, the Federal Democratic National Forum (FDNF), signed an agreement for the recognition of an ethnicity-based federal system in the new constitution. Following this change the UN Special Rapporteur for Indigenous Peoples Human Rights and Fundamental Freedoms, James Anaya, visited Nepal (Lama-Tamang 2010). Notably the Adivasi Janajati movement (AJM) during 2005-2009 was a major force in establishing democracy in Nepal. The AJM was able to champion the rights of indigenous peoples and inclusion as well as to rearticulate the meanings of such terms as representation, nation-state, democracy and citizenship, as well as what is meant by cultural and linguistic rights (Lama-Tamang, 2010: 5).

\section{Government acceptance}

The Interim Constitution of Nepal-ICN (2007) notes 'having determined for progressive restructuring of the state in order to resolve the existing problems of the country that are based on class, caste, region and gender'. In Article 33 (d), it says that the state shall have the responsibility "to carry out an inclusive, democratic and progressive restructuring of the State by eliminating its existing form of centralized and unitary structure in order to address the problems related to women, Dalits, Indigenous Nationalities, Madhesis, oppressed and minority communities and other disadvantaged groups, by eliminating class, caste, language, gender, cultural, religious and regional discrimination" (ICN, 2007: article 33d). Similarly, Article 13 states, "Provided that nothing shall be deemed to prevent the making of special provisions by law for the protection, empowerment or advancement of women, Dalits, Indigenous Nationalities, Madhesi or farmers, laborers or those who belong to a class which is economically, socially or culturally backward, or children, the aged, disabled or those who are physically or mentally incapacitated". And again, the Second Amendment to the Interim Constitution states that "Women, Dalits, Indigenous Nationalities, Madhesi communities, oppressed groups, the poor farmers and laborers, who are economically, socially or educationally backward, shall have the right to 
participate in state structures on the basis of principles of proportional inclusion" [(article 21) Government of Nepal, 2007].

This inclusion in the ICN (2007) clearly indicates that the government has made significant efforts to reduce cultural exclusion since 2006 and has recently adopted a secular attitude. It has acknowledged the need to include marginalized groups in the Constituent Assembly, provided a quota system for marginalized groups in the Nepal Police and Armed Police Force in 2007, drafted the Amendment Bill of Interim Constitution in 2007 which states greater inclusion for marginalized ethnic and caste groups (Janajati, Madhesis, Dalits) in the state, enacted Civil Service Bill 3 in 2007 which grants seat reservation to excluded peoples and the Interim Constitution which recognized the rights of historically marginalized groups and denounced discrimination and untouchability, introduced the ratification of the ILO convention in 2007 that will ensure the rights of the Janajati in culture, education, land, natural resources, traditional justice, recruitment, employment conditions, social security, health, and vocational training as well as the assurance of participation in governance, created the Memorandum of Understanding between the Ministry of Peace and Reconstruction and the Badi community in 2007 which ended the forced use of derogatory surnames and provided free schooling for children in the Badi community, and finally, the government enacted the Ordinance on Social Inclusion in 2009 which makes public service inclusive for marginalized groups. In triangulation with the UNDP's analysis, it is believed that this legislature holds promise for future ethnic stability (CIA, 2010; UNDP, 2009; as cited in CIFP, 2010: 4).

Furthermore, the Government of Nepal, in its Fiscal Year 2010/2011 policy and program announced five major steps to foster the traditional knowledge, customs, which has been directly and indirectly impacting the wellbeing of Nepalese ICs (see at Policies and Programs of the Government of Nepal referred in the reference), the following is one of the exemplary commitments:

1. All types of discriminations against religion, language and culture will be eliminated. A national policy will be formulated and implemented for the protection, utilization and mobilization of cultural heritage

(GoN 2010:11 paragraphs 82).

These policy directives indicate that the government of Nepal is committed to implementing the ratified ILO Convention No. 169 and in the process to include an article on fostering indigenous communal identity in new constitution and implement them by creating essential rules and regulation. If it happened, than Nepal will be able claim its exemplary position of social inclusions.

\section{Conclusion: Is it really a transformation?}

"Transformation is foremost a continuing process. It does not have an end point. Transformation is meant to create or anticipate the future. Transformation is meant to deal with the co-evolution of concepts, processes, organizations and technology. Change in any one of these areas necessitates change in all. Transformation is meant to create new competitive areas and new competencies. Transformation is meant to identify, leverage and even create new underlying principles for the way things are done. Transformation is meant to identify and leverage new sources of power" (Cebrowski, 2002).

Nepal maintains endemicism in many ways and it is unique in terms of culture, religion, and geography. Nepal is dominated by Hindu mythology; however, there is also influence from Buddhist philosophy and to some extent the Muslim and Christian faiths. The mainstream religious social system has not been favorable for the indigenous nationalities (IN) and IN knowledge has not been recognized. However, particularly from the 1990 s on, social transformation has been accelerating the mainstreaming of indigenous people's rights.

To foster the identity of indigenous nationalities, various national and international agencies including the non-state actors - i.e. nongovernmental organizations (NGOs), Civil Society Organizations (CSO), indigenous people's organization, and political parties of indigenous nationalities - are the key actors in generating public awareness of the rights of the indigenous community and groups. These stakeholders have been helpful in improving the wellbeing of the ICs as well acknowledging indigenous knowledge, particularly since 2007, when the democratic movement included ICs rights in their political agendas. I witnessed that the IC groups also have been stirring up movements to secure recognition. Now there are political parties, and an NGO network of ICs with a national coordinating body, who advocate for the ICs' wellbeing and rights. 
These actors are also stakeholders in creating the socio-economic and political grounds for social transformation. Transformation is a process which can be seen in every case in the biophysical and anthropogenic arena. However, transformation does not happen fast without intervention. Transformation is a global or a local phenomenon in religious, culture and socio-economic economic terms. In the context of diminishing the religious hegemony within society it is a complex phenomenon, which has been growing in Nepal particularly from 1990s (Bhandari and Oli, 2018). The issues of the indigenous nationalities have been getting clear responses in the world context; however, the case of Nepal is exemplary for its government's response, including ratification of ILO Convention No. 169 and preserving the rights of indigenous nationalities in the interim constitution of 2007. Transformation is an anthropogenic social and environmental process which is occurring everywhere in Nepal through various interventions (i.e. advocacy campaigns, publications, program intervention and lobbying). The policy implications are dependent on the social norms and values, which are transferred from generation to generation as traditions or cultural rituals by indigenous nationalities. With the realization of the importance of indigenous knowledge, non-state and state actors are working together. The role of international governmental and nongovernmental organizations is significant in this process.

As seen in the analysis above, the domination of Hindu tradition is breaking down slowly. The government of Nepal, which is still dominated by members of an extended Hindu family, has accepted the indigenous communal identity (e.g. through ratifying LO 169 and providing high-priority policy directives.). In addition, the ICs traditional knowledge, customs, spirituality etc. are freely in practice, today, positively impacting the wellbeing of Nepalese. However, they are not yet fully institutionalized, still subject to the slow processes of social transformation. Thus, it is too early to examine its implications. It is a subject of further research on how a country in transition tackles ongoing debate on mainstreaming indigenous knowledge.

\section{Acknowledgement}

Heartful thanks to Ms. Prajita Bhandari for her insightful comments, and input. I would also like to thank to Prameya, Manaslu for their positive comments and encouragements. I would also like to thank to the SocioEconomic Challenges team as well as reviewer panel for their input and comments.

\section{References}

1. Bhattachan, Krishna B. (2008). Traditional Local Governance in Nepal. Paper presented in a national seminar on Strengthening Decentralization and Good Governance in Nepal organized by the Political Science Association of Nepal (POLSAN) and Friedrich-Ebert-Stiftung (FES), Kathmandu, (April 21, 2002) republished by the Nepal Federation of Indigenous Nationalities (NEFIN), Kusunti, Lalitpur, Nepal. Retrieved from: http://www.nefin.org.np/articles/dr-krishna-b-bhattachan/419-traditional-local-governance-in-nepal.html.

2. Bhattachan, Krishna B. and Chemjong, Dambar (2006). International Labor Organization Project to Promote the Rights of Indigenous Peoples (PRO 169) Achieving the Millennium Development Goals among the Indigenous Surels of Nepal, ILO, Geneva, Switzerland. Retrieved from: http://bravo.ilo.org/wcmsp5/groups/public/---ed_norm/---normes/documents/publication/wcms 100609.pdf.

3. Bhattachan, Krishna B. and Webster, Sarah (2005). Indigenous Peoples, Poverty Reduction and Conflict in Nepal, International Labor Organization, Project to Promote ILO Policy on Indigenous and Tribal Peoples (PRO 169) International Labor Office, CH-1211 Geneva 22, Switzerland.

4. Bhattachan, Yasso Kanti (2005) "Consultation and Participation of Indigenous Peoples in Decision-making in Nepal." Pp. 79-108. In: ILO Convention No. 169 and Peace Building in Nepal. Edited by Sarah Webster and Om Gurung. Kathmandu: NEFIN and ILO, Nepal. Retrieved from: http://ilo-mirror.library.cornell.edu/public/english/standards/norm/egalite/itpp/activity/nepal/yasso.pdf.

5. Bhandari, Medani P. (2018). Green Web-II: Standards and Perspectives from the IUCN, Published, sold and distributed by: River Publishers, Denmark / the Netherlands ISBN: 978-87-70220-12-5 (Hardback) 978-87-70220-11-8 (eBook),

6. Bhandari, Medani P. and Oli, Krishna P. (2018). The changing roles and impacts of civil society/NGOs in Nepal, Civil Society in the Global South (Palash Kamruzzaman edits.), Routledge, Taylor \& Francis Group, UK. 70-87. 
7. CBS (2018). Statistical Year Book Nepal 2017, Government of Nepal, National Planning commission, Central Bureau of Statistics, Ramshahpath, Thapathali, Kathmandu, Nepal https://cbs.gov.np/statisticalyear-book-2017/.

8. CBS (2001 to 2008). Nepal in figures, Central Bureau of Statistics, National Planning Commission, Government of Nepal, Thapathali, Kathmandu.

9. Cebrowski, Arthur K. (2002). The State of Transformation, presentation to Center for Naval Analyses, Crystal City, VA (20 November 2002).

10. CIA (2010). Worldfactbook, Nepal The Central Intelligence Agency (CIA), US Government, Washington DC. Retrieved from: https://www.cia.gov/library/publications/the-world-factbook/geos/np.html (accessed on 09/23/2010).

11. CIFP (2010). Nepal Risk Assessment in Brief, Country Indicators for Foreign Policy (CIFP), Carleton, University, Canada. Retrieved from: http://www.carleton.ca/cifp/app/serve.php/1267.pdf (accessed on $09 / 23 / 2010)$.

12. Dahal, G. R. (2006). Governance and institutional structure: An ignored dimension of devolution policy process in forestry (the case of community-based forest management in the Philippines)', PhD thesis, International and Rural Development Department, University of Reading, Reading, UK.

13. Dangal, Rameshwor (2005). Administrative Culture In Nepal: Does It Reflect The Dominant Socio-Cultural Values Of Nepal. A Thesis for the Master of Philosophy in Public Administration, Department of Administration and Organization Theory, University of Bergen, Norway (this document is available at UNPAN - United Nations Public Administration Network).

14. Dohrenwend, Bruce P. (1959). Egoism, Altruism, Anomie, and Fatalism: A Conceptual Analysis of Durkheim's Types, American Sociological Review, 24(4) (Aug., 1959), pp. 466-473.

15. Durkheim, Emile (1951). Suicide. Translated by John A. Spaulding and George Simpson, Glencoe, Ill.: Free Press.

16. Elder, Joseph W. (1966). Fatalism in India: A Comparison between Hindus and Muslims. Anthropological Quarterly, 39(3), Fatalism in Asia: Old Myths and New Realities (Special Issue), 227-243.

17. Fisher, James (1987). Romanticism and Development in Nepalese Anthropology. In Occasional Papers in Anthropology (Ed. James Fisher), Vol. 1. Tribhuvan University. Kathmandu, Nepal.

18. Giuseppe da Rovato, Father, (1970). Account of the Kingdom of Nepal; being an account of the consolidation of power within the Cat'hmandu Valley by Prit'hwinarayan, founder of the Shah Dynasty, during the years, Indian Offset Press, Delhi, India.

19. Griffin, D. M., Shepherd K. R., and Mahat T. B. S. (1988). Human Impact on Some Forests of the Middle Hills of Nepal, Part 5. Comparisons, Concepts, and Some Policy Implications, Mountain Research and Development, 8(1), 43-52.

20. Government of Nepal (2007). The Interim Constitution of Nepal-ICN, Singhadarbar, Kathamndu, Nepal

21. Government of Nepal - GoN (2010) Policies and Programs of the Government of Nepal for the Fiscal Year 2066/067, Office of the Prime Minister and Council of Ministers, Singh Durbar, Kathmandu, Nepal. Retrieved from: http://www.opmcm.gov.np/index.php?param=p6.

22. Gurung, Harka, Yogendra Gurung and Chhabi Lal Chidi (1996). Nepal Atlas of Ethnic and Caste Groups, Kathmandu: National Foundation for Development of Indigenous Nationalities, ISBN 99946-823-3-4.

23. Gurung, Om (2009). Major Challenges for Implementing ILO Convention 169 in Nepal, Paper Presented in a Three-Day Seminar "Should States Ratify Human Rights Conventions"? Organized by the Center of Advanced Studies, Oslo, Norway (August 18-20, 2009).

24. Gyawali, Dipak (2009). Water and conflict: Whose ethics is to prevail? in M. Ramon Llamas, Manuel Ramón Llamas edits Water Ethics: Marcelino Botin Water Forum 2007, Taylor \& Francis, Routledge, USA.

25. Hamilton, F. B. (1819). An Account of Kingdom of Nepal and of the Territories Annexed to this Domain by the House of Gurkha. Edinburgh: Archibald Constable and Company.

26. Hiriyanna, M. (1953) Philosophy of Values, In: H. Bhattacharyya (ed.), The Cultural Heritage of India: Philosophies, Volume 3, 695 pp. Ramakrishna Mission Institute of Culture, Calcutta, India.

27. Hodson, B. H. (1817). Essays on the Language, Literature and Religion of Nepal and Tibet. London: Trubner and Company.

28. Husain, Asad (1970). British India's relations with the Kingdom of Nepal, 1857-1947: a diplomatic history of Nepal. George Allen and Unwin Limited, London. 
29. Lama-Tamang, Mukta (2010). Indigenous peoples' movement and challenges of ILO C 169 implementation in Nepal, paper on Forum for Development Cooperation with Indigenous Peoples, Forum Conference 2010, Norway (October 24-30, 2010)

30. ILO (2011). Origins and history, ILO, Geneva, Switzerland. Retrieved from: http://www.ilo.org/global/about-the-ilo/history/lang--en/index.htm.

31. ILO-Nepal (2010). Labor and Social Trends in Nepal 2010, International Labor Organization, and National Planning Commission, Government of Nepal, International Labor Office, CH-1211 Geneva 22, Switzerland. Retrieved from: http://www.ilo.org/wcmsp5/groups/public/---asia/---ro-bangkok/---ilokathmandu/documents/publication/wcms_151322.pdf.

32. ILOLEX - 2. 5. 2011). Retrieved from: http://www.ilo.org/ilolex/cgi-lex/ratifce.pl?Nepal (2. 5. 2011) ILOLEX (4. 29. 2011)

33. International Work Group for Indigenous Affairs (IWGIA) (2011). What is self-determination, International Work Group for Indigenous Affairs, Copenhagen, Denmark.

34. Karan, Pradyumna P. (1960). Nepal, a cultural and physical geography, with the collaboration of William M. Jenkins (1960), University of Kentucky Press (map cited from page 2, greater Nepal).

35. Khanal, Yadu Nath (1966). Stray thoughts, Rakesh Press, Delhi, India.

36. Kirk Patric, C W. (1811). An Account of the Kingdom of Nepal. London: William Miller.

37. Lama-Tamang, Mukta S. (2010). Adivasi Janajati exclusion: Status and trend update (June 2005-April 2009), The Magar Study Center, Kathmandu, Nepal. Retrieved from: http://magarstudiescenter.org/wpcontent/uploads/2010/03/Adivasi_Janajati_draft.pdf.

38. National Bureau of Statistics-NCS (2004). Population Monograph of Nepal, National Bureau of Statistics, Government of Nepal, Thapathali, Kathmandu..

39. NPC (2017). Demographic Changes of Nepal:Trends and Policy Implications, National Planning Commission, Government of Nepal, National Planning Commission, Kathmandu, Nepal. Retrieved from: https://www.npc.gov.np/images/category/Demographic_Dividend_Report_May_2017_final_for_circulation1.pdf.

40. National Panning commission-NPC (2008). National Plan of 2008-2013, National Panning Commission, Government of Nepal, Sidhdarbar, Kathmandu, Nepal.

41. Nepali-times (2011). ILO 169: Nepal as a model, Nepali-times, From Issue \#541 (18 Feb 2011 - 24 Feb 2011), Kathmandu, Nepal. Retrieved from: http://www.nepalitimes.com/issue/2011/02/18/FromtheNepaliPress/17961.

42. Oldfield, N.A. (1880). Sketches from Nepal, London: Allen and Company.

43. Panday, Devendra Raj (2005). Democracy and Corruption. Liberal Democracy Nepal Bulletin, 1(2).

44. Ortner, Sherry (1978). Sherpas Through Their Rituals. Cambridge: Cambridge University Press.

45. Percival, P. (1982). Manava Dharma Sastra or the Institutes of Manu According to the Gloss of Kulluka, Translated by Sir William Jones (AES reprint of 1825 and 1863), Asian Educational Services, New Delhi, India.

46. Regmi, D. R. (1960). Ancient Nepal, Firma K.L. Mukhopadhyay, Culcutta, India.

47. Roy, Raja Devasish and Henriksen, John B. (2010). Inclusion of Indigenous Peoples' Rights in the New Constitution of Nepal, International Labor Organization, Geneva, Switzerland. Retrieved from: http://www.ilo.org/wcmsp5/groups/public/---ed_norm/---normes/documents/publication/wcms_123847.pdf

48. Savada, Andrea Matles (1991). Nepal country studies, United States of America, the Federal Research Division, Country Studies/Area Handbook Program, Library of Congress, Washington, D.C. 20540-5220. Retrieved from: http://www.country-data.com/cgi-bin/query/r-9062.html (accessed on 08/26/2010).

49. Sharma, P.R. (1977) Caste, Social Mobility and Sanskritization in the Tribal-Hindu Society: A Study of Nepal's Old Legal Code. Kailash, 5(4), 277-299.

50. Srinivas, M. N. (1952). Religion and Society among the Coorgs of South India. Oxford: Clarendon Press [esp. ch. 7, "Hinduism"].

51. Thapa, Netra B. (1967) Short history of Nepal, Reviewed by M. D. Moran (in 1967), Rantna Pustak Bhandar, Kathmandu.

52. Turin, Mark (2007) Harka's maps, Three new Nepal atlases are as interesting for what they tell as for what they miss, Nepali-times, From Issue \#333 (26 Jan 2007 - 01 Feb 2007), Kathmandu, Nepal. Retrieved from: http://www.nepalitimes.com/issue/333/Nation/13160. 
53. UNDP (2008) The Dalits of Nepal and a New Constitution, A Resource on the Situation of Dalits in Nepal, their Demands and the Implications for a new Constitution, United Nations Development Program (UNDP) Nepal, UN House, Pulchowk, Kathmandu, Nepal. Retrieved from: http://www.ccd.org.np/new/publications/dalit\%20of\%20nepal\%20and\%20a\%20new\%20constituition.pdf (accessed on 09/23/2010).

54. UNDP (2009) Nepal Human Development Report 2009, Nepal, UNDP, Nepal. Retrieved from: http://hdr.undp.org (accessed on 09/23/2010).

55. UNESCO (2006) Form and Pattern of Social Discrimination, in Nepal, United Nations Educational, Scientific and Cultural Organization office in Kathmandu (reported by Mr. Dambar Chemjong, Mr. Surendra Mishra, Mr. Sanjeev Pokhrel and Mr. Nabin Rawal). Retrieved from: http://unesdoc.unesco.org/images/0014/001460/146086e.pdf.

56. United Nations (1948) Universal Declaration of Human Rights, United Nations, New York, USA. Retrieved from: http://www.un.org/en/documents/udhr/index.shtml.

57. United Nations (2009) State of the World's Indigenous Peoples, Department of Economic and Social Affairs, Division for Social Policy and Development, Secretariat of the Permanent Forum on Indigenous Issues, United Nations, New York. Retrieved from: http://www.un.org/esa/socdev/unpfii/documents/SOWIP web.pdf.

58. United Nations (2009) General Assembly, United Nations, New York.

59. Whelpton, John (2005) "A Reading Guide to Nepalese History," Himalaya, the Journal of the Association for Nepal and Himalayan Studies: Vol. 25: No. 1, Article 5. Retrieved from: http://digitalcommons.macalester.edu/himalaya/vol25/iss 1/5/ (accessed on 08/26/2010).

60. Whelpton, John (2005) A history of Nepal, Cambridge University Press. Retrieved from: http://bilder.buecher.de/zusatz/12/12951/12951357_vorw_1.pdf (accessed on 08/26/2010). 
Appendix 1. Situation of Nepal's Indigenous Nationalities

\begin{tabular}{|c|c|c|c|}
\hline Endangered Group & Highly Marginalized Group & Marginalized Group & Disadvantaged Group \\
\hline 1.Kusunda & 1.Majhi & \multirow{15}{*}{$\begin{array}{l}\text { 5.Kumal } \\
\text { 6.Rajbangshi } \\
\text { 7.Gangaai } \\
\text { 8.Dhimal } \\
\text { 9.Bhote } \\
\text { 10.Darai } \\
\text { 11.Tajpuriya } \\
\text { 12.Pahari } \\
\text { 13.Topkegola } \\
\text { 14.Dolpo } \\
\text { 15.Fri } \\
\text { 16.Mugal } \\
\text { 17.Larke } \\
\text { 18.Lohpa } \\
\text { 19.Dura } \\
\text { 20.Walung }\end{array}$} & \multirow{15}{*}{$\begin{array}{l}\text { 1. Chhairotan } \\
\text { 2.Tanbe } \\
\text { 3.Tingaunle Thakali } \\
\text { 4.BaragaunleThakali } \\
\text { 5.Marphali Thakali } \\
\text { 6. Gurung } \\
\text { 7.Magar } \\
\text { 8.Rai } \\
\text { 9.Limbu } \\
\text { 10.Sherpa } \\
\text { 11.Yakkha } \\
\text { 12.Chhantyal } \\
\text { 13.Jirel } \\
\text { 14.Byansi } \\
\text { 15.Yolmo }\end{array}$} \\
\hline 2.Bankariya & 2.Siyar & & \\
\hline 3.Raute & 3.Lhomi (shinsaba) & & \\
\hline 4.Surel & 4.Thudam & & \\
\hline 5.Hayu & 5.Dhanuk & & \\
\hline 6.Raji & 6.Chepang & & \\
\hline 7.Kisan & 7.Santhal & & \\
\hline 8.Lepcha & 8.Jhagad & & \\
\hline 9.Meche & 9.Thami & & \\
\hline 10.Kuswadiya & 10.Bote & & \\
\hline & 11.Danuwar & & \\
\hline & 12.Baramu & & \\
\hline \multirow{3}{*}{$\begin{array}{l}\text { Advanced Group: } \\
\text { 1. Newar and 2. Thakali- } \\
\text { Total: } 59 \text { Indigenous } \\
\text { Nationalities }\end{array}$} & & & \\
\hline & Marginalized Group & & \\
\hline & $\begin{array}{l}\text { 1.Sunuwar } \\
\text { 2.Tharu } \\
\text { 3.Tamang } \\
\text { 4.Bhujel }\end{array}$ & & \\
\hline
\end{tabular}

Source: The table shows the Situation of Indigenous Nationalities of Nepal (Bhattachan, 2008). 